\title{
Kisspeptin (kiss 1) network signaling of hypothalamic gonadotropin-releasing hormone (GnRH) neurons
}

\author{
F. Przekop ${ }^{1}$ and M. Ciechanowska ${ }^{2,3}$ \\ ${ }^{I}$ The Kielanowski Institute of Physiology and Nutrition, Polish Academy of Sciences, \\ Department of Neuroendocrinology \\ Instytucka 3, 05-110 Jabłonna, Poland \\ ${ }^{2}$ The General Karol Kaczkowski Military Institute of Hygiene and Epidemiology, \\ Department of Pharmacology and Toxicology \\ Kozielska 4, 01-163 Warsaw, Poland
}

(Received 26 June 2012; revised version 1 August 2012; accepted 29 August 2012)

\begin{abstract}
To regulate reproduction in mammals, internal and external status is communicated to the hypothalamic-pituitary-gonadal axis via a coordinated balance of stimulatory and inhibitory neurochemical systems. This review describes the neuroanatomical organization of the kisspeptin system in the hypothalamus, and summarizes its role in signaling hypothalamic GnRH neurons, namely: multimodal actions of kisspeptin in the control of $\mathrm{GnRH}$ secretion during different physiological states of animals; involvement of kisspeptin in relaying metabolic information to hypothalamic GnRH neurons; neurobiological mechanisms underlying kisspeptin activation of GnRH neurons during puberty onset; effect of gonadal steroids in the early postnatal period in rodents on kisspeptin expression in the hypothalamus and gonadotropin secretion in adults; effect of photoperiod and metabolic cues on the activation/inhibition of hypothalamic-pituitary-gonadal axis in seasonally breeding species by kisspeptin.
\end{abstract}

KEY WORDS: hypothalamus, kisspeptin neurons, GnRH, rodents, sheep, primates

\section{INTRODUCTION}

Kisspeptin 54 (termed kiss 1) has recently emerged as a key player in the regulation of many physiological functions, among which the most recognized is

\footnotetext{
${ }^{3}$ Corresponding author: e-mail: mciechanowska@wihe.waw.pl
} 
elicitation of GnRH secretion (Seminaria et al., 2003; Smith et al., 2006c).

Compelling experimental evidence has strongly suggested the involvement of kisspeptin in many physiological processes of reproduction, including positive and negative feedback of sex steroids on gonadotropin secretion (Terasawa et al., 2010), generation of the preovulatory GnRH surge (Lehman et al., 2010), metabolic regulation of fertility (Roa et al., 2008), photoperiodic control of reproduction in seasonal breeders (Chalivoix et al., 2010), maturation and timing of puberty onset (Amstalden et al., 2010 b; Clarkson et al., 2010), sex and speciesspecific differences of kisspeptin neurons in signaling hypothalamic GnRH cells (Homma et al., 2009; Kauffman et al., 2009), the effect of gonadal steroids in early postnatal life in rodents on kisspeptin expression in the hypothalamus and gonadotropin secretion in adult females and males (Kauffman et al., 2009).

In rodents, kisspeptin expression in the hypothalamus and gonadotropin secretion in adult females and males are affected by gonadal steriods acting in the early postnatal period.

In a wide range of mammals, such as mice, rats, sheep, pigs and primates, kiss $1 \mathrm{mRNA}$ or kisspeptin protein have been detected mainly in two distinct regions within the hypothalamus: the first is in the preoptic area, which in rodents constitutes a morphological continuum comprising the anteroventral hypothalamus (AVPV) region, the second is the more caudally situated arcuate nucleus (ARC) (Oakley et al., 2009). In rodents, two discrete subpopulations of kiss 1 neurons with different functional properties in response to oestrogens exist in the ARC and AVPV. The neurons of kisspeptin in the ARC have been implicated in the negative feedback action of oestrogens, while AVPV kisspeptin cells in female rodents may participate in the positive feedback action of gonadal steroids (Kauffman et al., 2009) (Figure 1).

Kisspeptin, encoded by the kiss 1 gene, is a high-affinity peptide ligand (West et al., 1998) for the orphan G-protein-coupled membrane receptor (GPR 54) called kiss $1 \mathrm{r}$ (Ohtaki et al., 2001). The initial product of the kiss 1 gene (Oakley et al., 2009 ) is a 145 -amino acid protein that is enzymatically cleaved into a 54-amino acid peptide, known as kiss 1 . There are also shorter peptides (kisspeptin 10, 13, 14 amino acids ) that share the RF amidated motif of kiss 1 (Figure 1). It is likely that kiss 1 is unstable and proteolyticaly cleaves into these shorter products (Kotani et al., 2001). However, all four peptides exhibit the same affinity and efficiency for kiss $1 \mathrm{r}$, indicating that the $\mathrm{C}$ terminal end of the peptides is responsible for the binding and activation of kiss $1 \mathrm{r}$. Although all of these kisspeptin products are biologically active, the in vivo relevance of the shorter forms is less recognized (Oakley et al., 2009). The binding of kisspeptin to kiss 1r leads to a cascade of reactions, from the activation of $\mathrm{G}$ protein phosphatase C (PLCB), synthesis of intracellular second messengers, inositol triphosphate (IP3) and diacylglycerol 


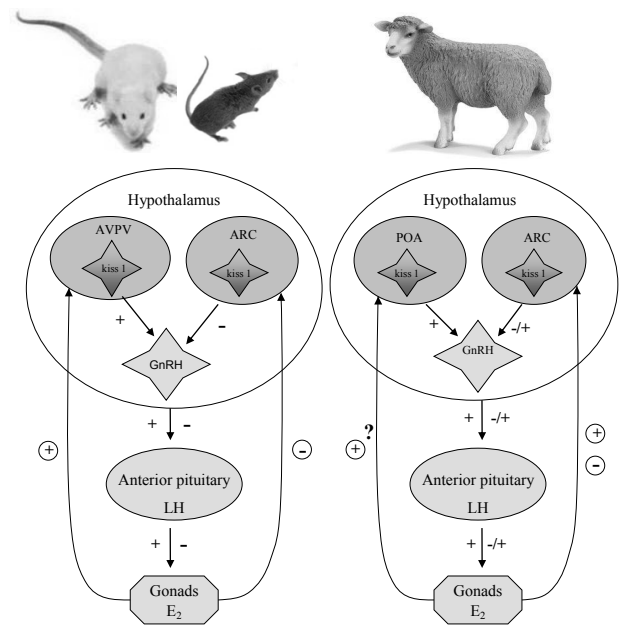

Figure 1. The schematic comparison of positive and negative feedback inputs into the hypothalamicpituitary-gonadal axis through kisspeptin (kiss 1) neurons in the anteroventral periventricular nucleus (AVPV), arcuate nucleus (ARC) and preoptic area (POA) within the hypothalamus of rodents and sheep. GnRH - gonadotropin releasing hormone, LH - luteinizing hormone, $\mathrm{E}_{2}$ - oestradiol, + - stimulation, - - inhibition, $\oplus$ - positive feedback action, $\ominus$ - negative feedback action

(DAG), to intracellular $\mathrm{Ca}^{++}$release and activation of protein kinase $\mathrm{C}$ (PKC) (Oakley et al., 2009). Kisspeptin stimulates GnRH secretion through a phospholipase $\mathrm{C} /$ calcium-dependent pathway regulating multiple ion channels (Zhang et al., 2008).

The kiss 1 neurons in many discrete nuclei of the hypothalamus and other brain regions, as well as outside the central nervous system (CNS) varies across species (Lee et al., 2009; Oakley et al., 2009). In the murine hypothalamus, kiss 1 mRNA and kiss-immunoreactive cell bodies are expressed mostly in the AVPV, periventricular nucleus (PeV), ARC, and dorsomedial hypothalamus (DMH) (Clarkson et al., 2009; Oakley et al., 2009). In addition, cells expressing kiss $1 \mathrm{mRNA}$ are located in the preoptic area (POA) and bed nucleus of stria terminals (BNST) (Oakley et al., 2009). Although the distribution of kisspeptin cells is similar between males and females, there are significant sex differences in the number of cell bodies in the AVPV/PeV. The adult female mouse exhibits about 10-fold more kisspeptin immunoreactive cells than do males (Messager et al., 2005; Oakley et al., 2009).

In the rat hypothalamus, kiss 1 cells are found in the AVPV/PeV, ARC, DMH, paraventricular nuclei (PV), and ventromedial hypothalamus (VMH). Most of the kisspeptin cells in this species are located in the DMH, but cells containing kiss 1 
mRNA have not been detected in this structure by in situ hybridization (Oakley et al., 2009). Similarly, antibodies do not label kisspeptin neurons in the AVPV/ $\mathrm{PeV}$, in which high expression of kiss 1 mRNA has been established (Oakley et al., 2009). In adult female rats, the AVPV contains about 25 times more cells that express kiss 1 mRNA compared with males (Kauffman et al., 2007a; Oakley et al., 2009). The hypothalamic GnRH cells in mice and rats also co-express kiss 1 mRNA (Irwing et al., 2004; Oakley et al., 2009; Clarkson et al., 2010).

In the Syrian hamster, a rodent with ovarian cycles during a long-day photoperiod, such a photoperiod increases kisspeptin in the ARC (Roseweir et al., 2009 ). Levels of kiss 1 mRNA in the ARC are reduced in male Syrian hamsters after transfer from long-day to short-day conditions, which leads to reproductive quiescence (Revel et al., 2007). Chronic infusion of kisspeptin restores testicular activity in this species despite persistence of photoinhibitory conditions (Revel et al., 2006). On the other hand, in Siberian hamsters, kisspeptin and kiss $1 \mathrm{mRNA}$ expression increase in the ARC and decrease in the AVPV after transfer to a short photoperiod (Paul et al., 2009b). Both male and female Siberian hamsters held under short-day conditions exhibit a reduced response to exogenous kisspeptin treatment and show negligible kisspeptin expression in the AVPV and high expression in the ARC (Mason et al., 2007). Under long-day conditions, the expression of kiss 1 is increased in the AVPV and a only minor elevation is observed in the ARC (Greives et al., 2007; Mason et al., 2007).

In sheep, a short-day breeding species, most kisspeptin immunoreactive cells are detected in the ARC, DMH, POA, VMH, and in the caudal part of the PV (Pompolo et al., 2006; Oakley et al., 2009). Kiss 1 mRNA expression in the ARC is lower during seasonal anoestrus than during the breeding season (Smith et al., $2008 \mathrm{~b}$ ). There also exist sex differences in the number of kisspeptin neurons in the ovine hypothalamus: adult rams have nearly half the number of kisspeptin neurons in the ARC as do females (Cheng et al., 2010). In contrast to rodents, the GnRH cells in the hypothalamus of sheep do not express kisspeptin (Oakley et al., 2009).

\section{MULTIMODAL ACTION OF KISSPEPTIN NEURONS IN THE HYPO- THALAMUS ON GNRH CELLS: FACTORS AFFECTING KISSPEPTIN NEURON ACTIVITY}

The control of kisspeptin neuron activity comes from a variety of sources, including steroid hormones (Oakley et al., 2009), peptides (Backholer et al., 2010a,b), photoperiodic cues (Chalivoix et al., 2010), metabolic signals (Fernandez-Fernandez et al., 2006), and others (Plant et al., 2006; Kauffman et al., 2009; Oakley et al., 2009). 
Some influences of kisspeptin on reproductive processes are highly conserved across species, such as involvement of kisspeptin neurons in the negative feedback action of oestrogen on GnRH release (Oakley et al., 2009). Other aspects of oestradiol on GnRH secretion through kisspeptin systems in different hypothalamic structures are unique to particular species and gender, like the stimulatory action of oestrogen on GnRH release in females (Oakley et al., 2009) or its influence in the early postnatal period in females and males on kisspeptin neuron expression in adulthood (Kauffman et al., 2009). Similarly, kisspeptin neurons react in a specific way to the duration of light in seasonally breeding animals (Greives et al., 2007; Revel et al., 2007). Generally, the level of kisspeptin in these animals is higher during the breeding season compared with the non-breeding anoestrous period. For example, in long-day seasonal breeders like the Syrian hamster, the expression of kiss $1 \mathrm{mRNA}$ in the ARC rises in the long-day photoperiod, while in ewes, short-day breeding animals, its increased expression in this area occurs during the seasonal short day (Smith et al., 2007; Oakley et al., 2009).

Kisspeptin neurons in the AVPV of rodents appear to play a central role in the positive feedback effect of oestradiol on GnRH cells. Indeed, nearly all kisspeptin neurons in this structure of female rodents express oestradiol receptors and treatment with oestradiol causes significant increases in the expression of kiss 1 mRNA (Oakley et al., 2009) in them. The expression of kiss 1 mRNA in the AVPV peaks at a time coincident with the GnRH/LH surge, and kisspeptin neurons in this structure show fos induction at the time of gonadotropin output (Smith et al., 2006a; Oakley et al., 2009). The positive feedback effect of oestradiol through the kisspeptin system in the AVPV on preovulatory release of GnRH is also suggested by other lines of evidence. Kisspeptin neurons from this area make direct synaptic contact with GnRH cells and treatment with kisspeptin antiserum completely abolishes the GnRH surge (Oakley et al., 2009; Pineda et al., 2010). The transient suppression of kisspeptin signaling prevents the occurrence of the primary surges of LH and FSH, and the secondary peak of FSH (Pineda et al., 2010) in rats. Nonetheless, despite the inhibition of hormonal surges, basal LH and FSH levels are not overtly decreased by administration of an antagonist of kisspeptin in cyclic female rats (Pineda et al., 2010).

Recent studies indicate that kisspeptin neurons also represent an important component of the negative feedback loop of oestradiol on GnRH release. This function is carried out by a subpopulation of kisspeptin neurons located mainly in the ARC (Navarro et al., 2004). The expression of kiss 1 mRNA in the ARC of rats changes throughout the oestrous cycle, with levels reaching a nadir at/or around the time when the oestradiol levels are highest (Smith et al., 2006a). On the other hand, a decrease in blood oestradiol concentrations after ovariectomy causes a rise in kiss 1 mRNA in the ARC of rodents, sheep, and monkeys (Navarro et al., 2004; Smith et al., 2007; Kim et al., 2009). 
In sheep, kisspeptin neurons have been found mainly in the ARC and POA (Oakley et al., 2009) and all cells in the ARC display both positive and negative feedback responses to oestradiol (Felip et al., 2009; Smith et al., 2009a), whereas in the POA, kiss is positively involved in the feedback action of oestradiol on GnRH/LH secretion (Smith et al., 2009a) (Figure 2). The positive feedback effect of oestradiol on GnRH neurons in sheep is mediated by kisspeptin neurons in the middle to caudal parts of the ARC, as revealed by up-regulation of kiss 1 mRNA during the periovulatory period (Smith et al., 2008b). Indeed, kisspeptin cells

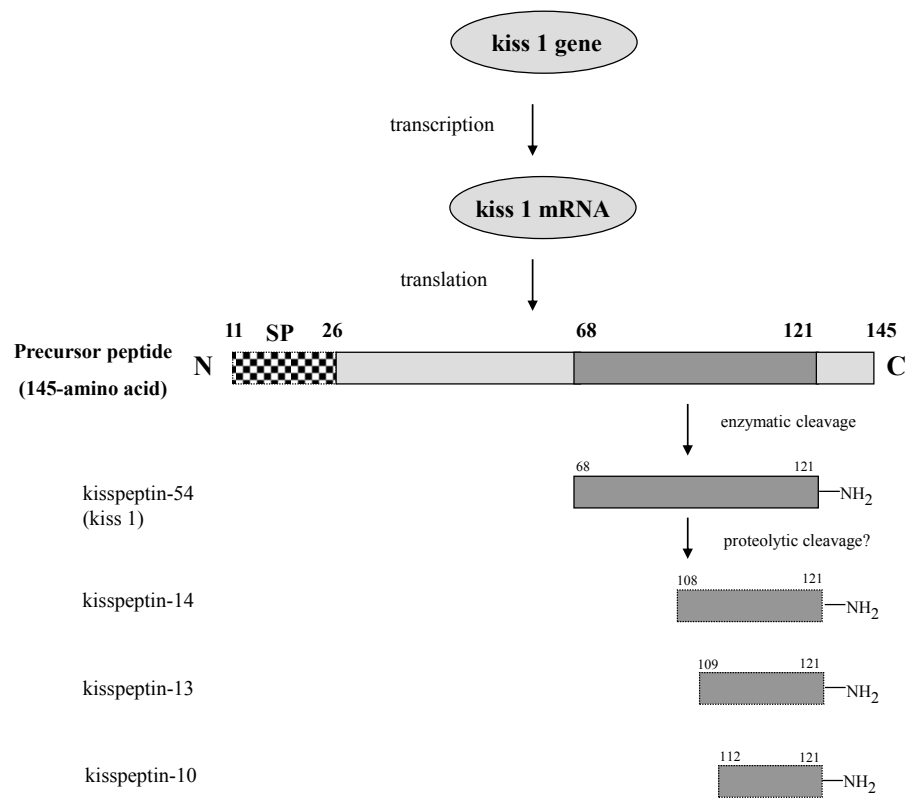

Figure 2. Schematic diagram showing posttranscriptional and posttranslational product of kiss 1 gene - 145-amino-acid precursor peptide, and relative cleavage points of precursor peptide that lead to the synthesis of kisspeptin-54 (named as kiss 1) and shorter peptides such as kisspeptin-10, -13, and -14). SP - signal peptide, $\mathrm{N}$ - amino-terminal domain, $\mathrm{C}$ - carboxyl-terminal domain

within this region of sheep became transcriptionally activated after $\mathrm{GnRH}$ surge-inducing oestradiol stimulus, and kisspeptin protein fos expression and kiss 1 mRNA were greater immediately prior to the GnRH surge (Smith et al., 2008b, 2009a), thus suggesting a stimulatory role of kisspeptin in oestrogenpositive feedback on GnRH secretion. On the other hand, the increase of GnRH/ LH secretion in ewes after ovariectomy with a concomitant rise in kiss 1 mRNA expression in the ARC indicates that at least the same subpopulation of kisspeptin cells in this area mediates the inhibitory effect of oestradiol on the activity of GnRH neurons (Smith et al., 2010). 
Recent studies evidenced that kisspeptin cells in the POA of ewes may also be involved in the positive feedback effect of oestrogen on GnRH secretion and preovulatory GnRH/LH surge. The increase of POA kiss mRNA in the follicular phase in ewes suggests that the POA kisspeptin cell subpopulation may also contribute to the stimulation of GnRH secretion during the surge (Smith et al., 2009b). It is suggested that in female sheep, the induction of GnRH release and preovulatory $\mathrm{GnRH} / \mathrm{LH}$ surge involves the sequential action of oestradiol on the ARC+POA kisspeptin cell populations (Lehman et al., 2010). It is possible that the early effect of oestrogen within the ARC is to sensitize the POA kisspeptin system for subsequent triggering of the GnRH surge (Caraty et al., 2010; Cheng et al., 2010).

Several lines of evidence indicate that kisspeptin signals directly to the GnRH system: the majority of GnRH cells in rodents express kiss 1 and kiss 1r (Oakley et al., 2009; Herbison et al., 2010), and kisspeptin fibres are closely associated with GnRH neurons (Clarkson et al., 2007). Kisspeptin can act directly to depolarize and increase firing rates of GnRH cells in vitro (Zhang et al., 2008) or through synaptic mechanism(s) (Oakley et al., 2009) to stimulate GnRH secretion. Kisspeptin neurons in the median eminence can affect $\mathrm{GnRH}$ cells in a nonsynaptic manner (Smith et al., 2007; Ramaswamy et al., 2008). The precise molecular mechanisms by which oestradiol differentially regulates kisspeptin cell activity is unknown. Oestrogen receptors can exert a multiplicity of cellular effects in kisspeptin neurons depending upon their interplay with different signaling pathways.

The classical pathways involves oestradiol binding to the gene promoter of oestrogen-sensitive neurons to alter transcription (Oakley et al., 2009). An alternative oestrogen receptor signaling pathway operates through a nonclassical mechanism with protein-protein interactions (Glidewell-Kenney et al., 2007; Gottsch et al., 2009). Analysis of these interactions in female mice indicates that the positive effect of oestradiol on the expression of kiss 1 is mediated by the classical pathway in the AVPV and by the nonclassical negative feedback regulation of LH release in the ARC (Gottsch et al., 2009; Oakley et al., 2009). These results show that kisspeptin neurons in the AVPV and ARC of rodents respond in a site-specific manner to the action of oestrogen on GnRH (Gottsch et al., 2009). The role of AVPV kisspeptidergic afferents in the generation of GnRH release should be viewed with caution, however, because opposite results of the persistence of the positive feedback of oestradiol have been reported in different mouse lines with a null mutation of kisspeptin receptors (Oakley et al., 2009). In studies based on models of congenital absence of kisspeptin or kisspeptin receptors, it has been shown that $\mathrm{GnRH} / \mathrm{LH}$ secretion persisted in many animals in which kisspeptin signaling was inactivated (Chan et al., 2009a,b), whereas in other models, inactivation led to complete reproductive failure (Clarkson et al., 2007; Dungan et al., 2007). 
There is still a lack of fundamental understanding of how kisspeptin neurons of the ARC in ewes mediate both negative and positive feedback of oestradiol on GnRH secretion. Indeed, oestradiol inhibits the kisspeptin-induced rise in LH secretion in mice and rats, and blocks the postcastration LH increase in rodents and sheep, suggesting a major role of kisspeptin neurons of this structure in mediating the negative feedback action of sex steroids on the hypothalamic-pituitarygonadal axis activity (Roseweir et al., 2009, 2010). Both the positive and negative feedback action of oestradiol evidenced in ewes raises questions how the same set of neurons can have both stimulatory and inhibitory effects on GnRH secretion in different physiological states. The new likely explanations are that subsets of neurons in the ARC of ewes mediate different actions of oestradiol or that the same subset of neurons responds differentially to low and high concentrations of steroids, perhaps through different intracellular signaling mechanisms. It is likely that oestradiol in the ARC acts via multiple pathways to induce the preovulatory GnRH surge or to inhibit basal GnRH secretion, one of these pathways may be through ARC kisspeptin/neurokinin B/dynorphin (KNDy) neurons (Lehman et al., 2010).

Very recently, the availability of the first factor with the ability to block kisspeptin action in vivo and in vitro, kisspeptin antagonist $\mathrm{p} 234$, has made it possible to characterize in detail the role of endogenous kisspeptin in the control of GnRH secretion. It has been shown that acute, transient suppression of kisspeptin signaling prevents the occurrence of a $\mathrm{GnRH} /$ gonadotropin surge, but does not alter basal LH and FSH secretion in rats. Blockade of kisspeptin receptors suppresses both GnRH and oestradiol-induced gonadotropin surges and increases LH secretion after gonadectomy, but does not affect basal secretion of these hormones in rats (Pineda et al., 2010).

The inhibition of LH and FSH surges by a kisspeptin antagonist without affecting basal gonadotropin secretion may be useful in designing therapeutic approaches in reproduction by selectively targeting surges without abolishing basal gonadotropin secretion (Pineda et al., 2010).

In the ARC, a subpopulation of ovine kisspeptin neurons expresses dynorphin and neurokinin B (Goodman et al., 2007; Cheng et al., 2010). The co-localization of KNDy peptide cells in the ARC is unique among brain regions and is conserved across multiple mammalian species that include rats, mice, goats, and humans (Lehman et al., 2010). A large body of evidence strongly suggests that KNDy cells and individual KNDy peptides can influence the activity of GnRH cells by acting directly at the level of their cell bodies in the POA and/or their neurosecretory terminals in the median eminence (Foradori et al., 2006; Lehman et al., 2010). This does not preclude also the possibility that projections of KNDy cells to interneurons, such dynorphin or kisspeptin neurons in the POA, play a major role 
in the control of GnRH release (Gottsch et al., 2009; Lehman et al., 2010).

Evidence in rats (Ciofi et al., 2006) and sheep (Billings et al., 2010) indicates that KNDy cells and their terminals colocalize with the vesicular glutamate transporter-2 (vGLUT-2), suggesting that they are glutaminergic as well as peptidergic in phenotype (Wu et al., 2009; Lehman et al., 2010). Colocalization of glutamate with kisspeptin cells and their projections onto GnRH neurons in the ewe suggest that co-release of kisspeptin and glutamate from ARC neurons may plays a physiological role in steroid feedback control of GnRH secretion (Lehman et al., 2010). The majority of vGLUT-2 positive cells in the ARC of the sheep are colocalized with oestrogen $\alpha$ receptors and provide a role for glutamate in conveying the feedback influence of oestradiol during the preovulatory $\mathrm{GnRH}$ surge (Lehman et al., 2010). It is suggested that the coordinated release of kisspeptin and glutamate provides dual stimulatory signals to activate either the KNDy subpopulation or GnRH neurons during the follicular phase of the oestrous cycle in ewes (Lehman et al., 2010). This point of view is supported by the observation that in the ARC of mice, N-methyl D-aspartic acid (NMDA), an NMDA receptor (NMDAR) agonist, causes an increase of c-fos expression in kisspeptin cells, thus suggesting the kisspeptin-dependent action of NMDA stimulating GnRH release (D'Anglemont de Tasigny et al., 2010). Although there is evidence that NMDAR are expressed on GnRH cell bodies as well as on GnRH terminals at the level of the median eminence, it is not known whether KNDy cells express these or other glutamate receptor subtypes (Lehman et al., 2010).

The ARC KNDy neurons also have receptors for dynorphin and neurokin B (NKB) (Navarro et al., 2009; Amstalden et al., 2010a), thus suggesting the existence of autosynaptic contact among KNDy; kisspeptin neurons generate pulses of kisspeptin release, which in turn drives pulsatile GnRH secretion (Tovar et al., 2006). It is possible that kisspeptin cells exert both a stimulatory and inhibitory influence on themselves and on another cells of this type. Indeed, peripheral administration of kisspeptin elicits $\mathrm{GnRH} / \mathrm{LH}$ pulses in rats and monkeys (Plant and Witchel, 2006; Tovar et al., 2006). Continuous delivery of exogenous kisspeptin can desensitize kiss 1, resulting in decreased LH secretion (Seminaria et al., 2006). This implies that the efficiency of kisspeptin on gonadotropin secretion depends on the pulsatile manner of its release. Interestingly, sustained kisspeptin treatment in seasonally anoestrous ewes increased LH secretion and caused ovulation in most animals (Caraty et al., 2007). It is likely that the endogenous kisspeptin in the ARC may be inhibited by oestradiol during negative feedback, and stimulated during positive feedback, which in turn may alter synaptic transmission to GnRH neurons.

Dynorphin A, an opioid peptide, is also a critical mediator in the negative feedback of progesterone in GnRH secretion (Cheng et al., 2010). In ewes 
dynorphin appears to act as an inhibitory factor on pulsatile GnRH secretion and mediates progesterone negative feedback on gonadotropin release during the luteal phase of the oestrous cycle (Lehman et al., 2010).

Similarly, the NKB is implicated in steroid feedback control of GnRH secretion, although its aspect may be species-specific; it has indirect stimulatory action on GnRH neurons in sheep and humans (Billings et al., 2010; Topaloglu et al., 2010), whereas in rats and mice its displays a rather suppressive influence on the secretion of this hormone (Corander et al., 2010; Lehman et al., 2010). Single ARC KNDy cell groups in ewes co-express both stimulatory and inhibitory neuropeptides, making alterations in the levels or release of each a potential mechanism for feedback control of GnRH neuron activity.

Kisspeptin increases gamma-aminobutyric acid (GABA)-ergic transmission directly or indirectly to GnRH neurons in an oestradiol-dependent manner and can increase GnRH neuron response to activation of GABA receptors in rats (Zhang et al., 2009; Pielecka-Fortuna and Moenter, 2010).

There is morphological evidence for the existence of an interrelationship between kisspeptin- and nitric-oxide-containing neurons in the control of GnRH secretion (Bellefontain et al., 2011). Preliminary data show that kisspeptin- and nitric-oxide-containing neurons stimulate $\mathrm{GnRH}$ cells directly or indirectly via action on synaptic afferents to GnRH neurons. Additionally, kisspeptin neurons may also talk to neuronal nitric oxide synthase (nNOS) neurons and promote nitric oxide (NO) production that could serve as an intermediately synchronizing 'switch' of GnRH secretion (Bellefontain et al., 2011). Recent studies have demonstrated that intracerebroventricular injection of NMDA induces nNOS neuron activation and LH release in kisspeptin- and kisspeptin receptor-knockout mice (Bellefontain et al., 2011)

Although kisspeptin does not participate directly in the control of metabolic function and energy expenditure (Backholer et al., 2010b, Donato et al., 2011), there is growing evidence that the hypothalamic kisspeptin system plays a key role in conveying metabolic information to GnRH neurons (Roa et al., 2008; George et al., 2011). A critical amount of energy reserve is necessary for maintenance of cyclicity and fertility in females in most cases. Ovulation is usually suppressed when animals are in negative energy balance induced by different events (Brown et al., 2008; Donato et al., 2011). In adult mice subjected to short-term fasting, there is a rapid decline in both kiss 1 and kiss $1 \mathrm{r}$ followed by a decrease in GnRH secretion (Levis et al., 2002). It has been reported that kiss $1 \mathrm{mRNA}$ is reduced in both prepubertal and adult male and female food-deprived rats (Roa et al., 2008, 2010). The levels of kisspeptin receptors in the ARC and POA are lower in hypogonadotropic lean animals than in animals of normal weight (Castellano et al., 2005; Backholer et al., 2010b). In the state of undernutrition, which reduces 
gonadotropin secretion, kisspeptin administration can reinstate reproductive function (Navarro et al., 2005b; Castellano et al., 2009).

Numerous orexigenic and anorectic peptides produced in the central nervous system and/or peripheral tissue are involved in the fine regulation of feeding and reproduction by kisspeptin neurons in the hypothalamus. The adipocytederived hormone, leptin, which signals the size of body energy stores, is likely to play a pivotal role in the kisspeptin system regulating reproductive function (Backholer et al., 2010b; Donato et al., 2011). In the mouse, kisspeptin cells in the ARC and POA express the signaling form of leptin receptor (Navarro et al., 2005a; Smith et al., 2006b) and leptin is able to act directly on the kisspeptin system or indirectly via modulation of afferent pathways to kisspeptin cells such as proopiomelanocortin/neuropeptide Y (POMC/NPY) neurons (Backholer et al., 2010b; Roa et al., 2010). Leptin is able to normalize kiss 1 gene expression in models of impaired gonadotropin secretion linked to hypoleptinaemia (Donato et al., 2011).

Kisspeptin neurons in the ovine ARC and POA respond to leptin; expression of kiss 1 mRNA to in response to leptin is affected by the physiological state (Backholer et al., 2010b). In lean, but not in normal animals, a decrease in kiss 1 gene expression, as well as putative secretion of LH, can be partially restored by leptin treatment (Backholer et al., 2010b). Additionally, leptin acts to down-regulate NPY gene expression in animals of normal weights, but not in lean animals (Ahima and Hileman, 2000; Backholer et al., 2010b). Leptin administration to leptin-deficient (ob/ob) or leptin-receptor-deficient (db/db) subjects induces puberty and fertility (Donato et al., 2011). Leptin levels fall during starvation and leptin administration blunts the fasting-induced suppression of LH and restores fertility (Donato et al., 2011).

It was shown that the POMC system within the brain is also an important factor in the regulation of energy balance and regulation of reproductive processes in many species. Using double-label fluorescent immune-histochemistry, a complex reciprocal connection between kisspeptin cells in the POA and ARC with POMC/ NPY cells has been documented (Backholer et al., 2009, 2010a). An important concept is that the kisspeptin system affects POMC/NPY neurons by altering their gene expression, allowing a means by which kisspeptin cells may modulate appetite-regulating neurons (Backholer et al., 2010a, 2010b) and indirectly control GnRH secretion (Kim et al., 2010). The kisspeptin reduces POMC and increases NPY gene expression (Backholer et al., 2010b). NPY displays an inhibitory effect on $\mathrm{GnRH} / \mathrm{LH}$ release and a stimulatory one on food intake (Clarke et al., 2005). Similarly to kisspeptin, leptin also positively regulates POMC gene expression in rodents (Thornton et al., 1997; Donato et al., 2011). Leptin administration in the hypogonadotropic state of lean ovariectomized ewes up-regulates POMC gene 
expression in lean ewes, partially restoring kiss $1 \mathrm{mRNA}$ expression in these animals, it is possible that transmission of leptin to GnRH cells predominantly occurs through melanocortin- but not kisspeptin systems (Backholer et al., 2010a). Indeed, activation of melanocortin receptors in lean animals restores LH levels, suggesting that down-regulation of the POMC system is the cause of the hypogonadotropic condition (Donato et al., 2011). Conclusive experimental evidence has been presented recently, showing that under physiological conditions, the actions of leptin in the control of GnRH function are indirect and likely conducted via the modulation of afferent pathways (Quennel et al., 2009).

TThe POMC prohormone is post-translationally cleaved to produce $\beta$-endorphin and melanocortins, $\alpha$-melanocyte-stimulating hormone $(\alpha-\mathrm{MSH})$, $\beta$ and $\gamma$-MSH (Backholer et al., 2009). Endogenous $\beta$-endorphin negatively regulates reproduction and stimulates food intake (Backholer et al., 2009), on the other hand, melanocortins reduce food intake (Watanabe et al., 1999; Backholer et al., 2009) and stimulate gonadotropin secretion acting via their respective receptors (Backholer et al., 2010a)

The orexigenic gut peptide, ghrelin, which plays a major role during negative energy balance to maintain whole-body energy homeostasis (Agata et al., 2009; Briggs and Andrews, 2011), also provides feedback information on metabolic status to kisspeptin neurons. It could directly or indirectly suppress GnRH/LH acting via opioid peptides, NPY, corticotropin-releasing hormone (CRH), and kisspeptin neurons under conditions of deficient nutrition (Agata et al., 2009; Forbes et al., 2009; Roa et al., 2010). Fragmentary results suggest that ghrelin negatively modulates the activity of the hypothalamic-pituitary-gonadal axis in rats; fasting, ghrelin treatment, or their combination, down-regulate kiss 1 expression in the POA and decrease pulsatile LH secretion (Kurose et al., 2005; Agata et al., 2009; Forbes et al., 2009; Roa et al., 2010). Ghrelin levels are reduced in lean ovariectomized ewes (Kurose et al., 2005), but it is unknown whether this affects kisspeptin expression in this species.

\section{EFFECTS OF GONADAL STEROIDS IN THE EARLY POSTNATAL PERIOD IN RODENTS ON KISSPEPTIN EXPRESSION IN THE HYPOTHALAMUS AND ON GONADOTROPIN SECRETION}

Kisspeptin in the hypothalamus has been recently recognized as an important regulator of GnRH neurons both in development and adulthood (Oakley et al., 2009). Numerous studies on different species have provided results supporting the mechanism(s) of kisspeptin neuron action via kiss 1r on GnRH cells (Kauffman et al., 2009). These works have documented that in rodents, kiss 1 gene expression in the AVPV is up-regulated by high levels of oestrogen; in the absence of gonadal 
steroids after gonadectomy in adult females, kiss 1 levels in this structure are decreased, leading to disappearance of the GnRH/LH surge (Smith et al., 2006a; Kauffman et al., 2009). Similarly, pharmacological or transgenic blockade of kisspeptin signaling prevents the preovulatory gonadotropin surge (Kinoshita et al., 2005; Pineda et al., 2010). Kisspeptin neurons in the AVPV of rodents are sexually differentiated; adult females have greater kisspeptin expression than males (Kauffman et al., 2007b). The sex differences in AVPV kiss 1 expression in adulthood likely account for the sex-specific ability of female, but not male, rodents, to produce a gonadotropin surge (Kauffman et al., 2009). Indeed, the number of kisspeptin neurons in the AVPV correlates with the ability or inability of an animal to generate an LH surge: adult females have high kiss 1 levels and can generate a GnRH/LH surge, whereas adult males have little AVPV kiss 1 expression and cannot produce a gonadotropin surge, even with oestradiol treatment (Kauffman et al., 2009).

This sexually-dimorphic reproductive physiology of gonadotropin secretion has been demonstrated to be differentiated during the perinatal action of sex steroids (Corbier, 1985). Female newborn rats do not normally secrete significant levels of gonadal hormones during the perinatal 'critical period'; the absence of high levels of circulating sex steroids in perinatal females results in their brain kiss 1 being differentiated to feminized (Handa and Gorski, 1985; Kauffman et al., 2009) - leading to the ability of these animals to generate a GnRH/LH surge in adulthood. Female newborn rats exposed to oestradiol or testosterone display masculinized levels of kisspeptin immunoreactivity in the AVPV in adulthood and cannot generate a GnRH/LH surge in response to sex steroid treatment (Bateman and Palisaul, 2008). They possess very few kisspeptin neurons in the AVPV as adults, similarly to normal adult males (Kauffman et al., 2007a, 2009) and show male-like levels of kiss 1 mRNA (Handa and Gorski, 1985).

In contrast to females, during the perinatal period of development male rats secrete testosterone, which induces masculinization of kisspeptin neurons in the AVPV; this is reflected in the low expression of kiss 1 mRNA in adults (Homma et al., 2009). Newborn rats castrated on the day of birth have high kiss 1 levels in the AVPV as adults (Homma et al., 2009), indicating that the AVPV kiss 1 system sexually differentiates under the influence of postnatal gonadal steroids (Homma et al., 2009; Kauffman et al., 2009). After oestradiol treatment, these rats can generate an LH surge similarly as females (Kauffman et al., 2009).

Sex differences in ARC kisspeptin neurons that mediate oestradiol negativefeedback regulation of GnRH secretion, which manifests during peripubertal development, are absent in adult rats and mice (Kauffman et al., 2007b, 2009); adult rodent females and males display similar high levels of kisspeptin expressionin in the ARC after gonadectomy and similar reduced kisspeptin expression after steroid 
replacement (Homma et al., 2009; Kauffman et al., 2009). Intact prepubertal male and female mice, however, express low levels of kisspeptin in the ARC, whereas kisspeptin levels significantly increase in gonadectomized females but not in males (Kauffman et al., 2009). The increased kisspeptin expression in ovariectomized early postnatal life of female mice indicates that there is no gonadal hormoneindependent suppression of ARC kisspeptin neurons in prepubertal female mice and suggests that the prepubertal female reproductive axis appears to be kept quiescent predominantly by gonadal hormone negative feedback (Oakley et al., 2009; Cheng et al., 2010). In contrast, in prepubertal males, ARC kiss 1 expression 2-4 days following gonadectomy was similar to that in intact males (Homma et al., 2009; Kauffman et al., 2009). This lack of increased kiss 1 expression after gonadectomy in prepubertal males shows that some non-gonadal mechanism(s) suppress ARC kisspeptin neurons in these males. Since adult mice of both sexes exhibit significant increases in ARC kiss 1 expression, this phenomenon indicates that sex differences in gonadal hormone-independent suppression of the ARC kisspeptin system exists only during the short period of prepubertal development. Also, prepubertal LH levels display the same sexually-dimorphic pattern as ARC kiss 1 expression in gonadectomized prepubertal females and males (Kauffman et al., 2009). Thus, the regulation of $\mathrm{GnRH} / \mathrm{LH}$ secretion during prepubertal development is sexually dimorphic.

Although gonadectomized prepubertal male mice did not exhibit short-term elevation of LH secretion and ARC kiss 1 expression, they increased ARC kiss 1 mRNA and LH levels in adulthood (Kauffman et al., 2009). Similarly as in male mice, a gonadal hormone-independent mechanism(s) has developed in primates to control gonadotropin secretion and puberty onset (Plant, 2006; Plant et al., 2006). Increased NKB and LH in response to gonadectomy in both sexes have been demonstrated in postpubertal female, but not male, mice. This suggests that gonadal hormone-independent mechanism(s) restrain kiss/NKB-associated activation of the male reproductive axis before puberty (Kauffman et al., 2007b). This is consistent with data from primates showing that gonadectomized juvenile monkeys do not display elevated LH before the normal age of puberty (Plant and Witchel, 2006) and also from human males with gonadal disgenesis (Topaloglu et al., 2010). The precise mechanism(s) of the action of the non-gonadal inhibitory factors involved in this process remains unknown, however.

In sheep, both the positive and negative feedback action of oestradiol on GnRH/ LH secretion is mediated by kiss 1 neurons in the ARC (Smith et al., 2008b). Recent studies on kiss 1 expression in adult male and female sheep have indicated that females possess a greater number of kisspeptin neurons in the ARC than males (Cheng et al., 2010). Prenatal testosterone treatment reduces dynorphin/neurokinin B (DYN/NKB) expression in the KNDy cells in the ARC but not the number 
B (DYN/NKB) expression in the KNDy cells in the ARC, but not the number of kisspeptin neurons, suggesting that multiple neuropeptides expressed by the same neurons may have different 'critical periods' for sexual differentiation and/or that the kisspeptin system of the ovine ARC is not sexually differentiated by prenatal sex steroid treatment (Cheng et al., 2010). The imbalance of neuropeptide DYN/ NKB expression within KNDy cells by prenatal testosterone treatment provides a potential explanation for defects in gonadal hormone feedback control of GnRH secretion seen in ewes (Clarke et al., 1997; Robinson et al., 1999). The basis for species differences in kisspeptin systems in the prenatal-neonatal period in response to oestradiol is not entirely known, however, but may be connected with species differences in the neural region mediating sex steroid feedback on GnRH secretion. In rodents, the positive feedback of oestradiol is mediated by the AVPV, whereas in sheep, the ARC is involved in the control of the preovulatory GnRH surge (Foster et al., 2006; Smith et al., 2008b).

\section{EFFECTS OF KISSPEPTIN ON PITUITARY GONADOTROPES}

In respect to the direct action of kisspeptin on gonadotropes, conflicting findings have been reported in mammals. Several studies have demonstrated that kisspeptin stimulates gonadotropin release in vitro from cultured rat, ovine, and bovine primary pituitary cells, suggesting that kisspeptin may act directly on gonadotropes to stimulate LH and FSH secretion (Muir et al., 2001; Tovar et al., 2006; Oakley et al., 2009). Kiss 1 and kiss $1 \mathrm{r}$ genes are expressed in rat gonadotropes and differentially regulated by oestradiol and GnRH (Richard et al., 2008). Kiss 1r mRNA is expressed in ovine pituitary cell fractions enriched for gonadotropes, which allows the possibility that kisspeptin is either a hypophysiotropic/neurosecretory factor in sheep or there are paracrine mechanisms involving kiss 1r signaling within the pituitary (Smith et al., 2008a). By contrast, other studies have shown no apparent effect of kisspeptin on in vitro gonadotropin secretion in cultured rat primary pituitary cells or pituitary fragments (Kotani et al., 2001; Ohtaki et al., 2001). Similarly, in in vivo experiments the direct effect of kisspeptin on pituitary gonadotropes failed to stimulate gonadotropin secretion in hypothalamic-pituitary disconnected ewes during steady-state conditions (Smith et al., 2008b). Whether gonadotropes are targets for kisspeptin action remains still unresolved in mammals.

INVOLVEMENT OF THE HYPOTHALAMIC KISSPEPTIN SYSTEM IN THE ONSET OF PUBERTY

Studies undertaken in many species indicate that kisspeptin-kisspeptin receptor signaling at the level of GnRH neurons is essential for normal puberty onset 
(Messager et al., 2005). They have identified the three most important features leading to the onset of puberty: the increase of kisspeptin receptor mRNA in the $\mathrm{GnRH}$ neurons of hypothalamus; a modest increase in the electrical response of $\mathrm{GnRH}$ neurons to kiss $1 \mathrm{r}$ activation across postnatal development; and the appearance of kisspeptin fibres surrounding GnRH neurons just prior to puberty onset (Clarkson et al., 2010). They also suggest that the key step in kisspeptin control of puberty is the regulation of kisspeptin synthesis within the kisspeptin cell populations located in the rostral periventricular region of the third ventricle (RP3V) in rats and mice (Clarkson et al., 2010). More specifically, the involvement of kisspeptin signaling in the timing of reproductive puberty onset was originally suggested on the basis of observation of the lack of puberty linked to congenital deficiency of kiss 1r (Oakley et al., 2009). In humans and mice, mutation or lack of kiss $1 \mathrm{r}$ results in failure to undergo puberty (Chan et al., 2009b; Roseweir et al., 2009). Similarly, mice lacking the kiss 1 gene exhibit absence of reproductive development (Thompson et al., 2004).

A marked increase in kiss 1 and/or kiss 1r expression is associated with the onset of puberty (Castellano et al., 2006; Amstalden et al., 2010b). It has been reported that the number of kisspeptin neurons in the AVPV of mice increases exponentially from the early postnatal period through puberty (Clarkson et al., 2010). The percentage of kiss $1 \mathrm{r}$ mRNA does not differ between juvenile and adult animals, however (Han et al., 2005). During this period the percentage of GnRH neurons responding to kisspeptin increases approximately from 25 to more than $90 \%$ in adults, suggesting that GnRH neurons become more sensitive to kisspeptin during postnatal development, and that kisspeptin neuron activity increases with increasing oestradiol secretion in growing female rats (Han et al., 2005). In intact female monkeys, kisspeptin transcript expression is three-fold greater in midpubertal stages compared with juvenile or early pubertal animals, corresponding to the progressive increase in kiss 1r mRNA from juvenile to midpubertal stages (Shahab et al., 2005). An increase of kisspeptin pulses was also observed at the time of puberty (Keen et al., 2008). In the monkey, the kisspeptin neurons in the ARC may be a source of the GnRH pulse generator, showing nearly coincident secretion of kiss 1 and GnRH (Keen et al., 2008). Altogether, these findings seem to provide strong support for an important role of the kisspeptin system in the hypothalamus in mediating puberty (Oakley et al., 2009). Such a statement should be viewed with caution, however, because the results from mice models of kiss 1 and kiss 1 r gene knockouts indicate the existence of a kiss 1/kiss $1 \mathrm{r}$ independent GnRH regulatory mechanism(s) (Oakley et al., 2009).

The molecular and cellular mechanisms that lead to the onset of puberty may differ markedly across species and gender (Kauffman et al., 2009). Studies on monkeys indicate that GnRH neurons are already mature before puberty, but GnRH 
release is suppressed by tonic GABA activation. Blocking endogenous GABA activity with the GABAA receptor blocker bicuculline, significantly increases kisspeptin release, which plays an important stimulatory role in the prepubertal increase of GnRH release (Terasawa et al., 2010). Thus, the interplay between GABA, kisspeptin and GnRH neural systems appears to trigger puberty onset at least in this species. Blocking the action of kisspeptin by the action of $\mathrm{p} 234$ makes it possible to characterize the timing of puberty: vaginal opening and changes in uterine and ovarian weights at the expected time of puberty with concomitant analysis of gonadotropin secretion. The kisspeptin antagonist inhibits the firing rates of GnRH neurons, GnRH secretion, and suppresses LH responses to exogenous kiss 1 and gonadectomy (Pineda et al., 2010). This suggests that the delay in puberty of animals treated with $\mathrm{p} 234$ might be caused by central inhibition of the afternoon surges of LH that precede the occurrence of vaginal opening (Ojeda and Skinner, 2006; Pineda et al., 2010). The phenotypic effects of gonadotropin cells are not apparently associated with the decrease in mean circulating levels of LH and FSH at the end of antagonist treatment. These observations are in accordance with data from adult rats, where administration of $\mathrm{p} 234$ suppress LH release resulting from gonadectomy, but not basal gonadotropin secretion (Roseweir and Millar, 2009).

Recently, a new model was proposed for the mechanism of ARC KNDy neuron participation and for their action in the control of human reproduction. It is suggested that neurokinin B and dynorphin A act autosynaptically to synchronize pulsatile secretion of kisspeptin in the ARC, which in turn drives the release of GnRH in the median eminence (Foradori et al., 2006). It is still unclear whether the role of NKB in pubertal onset is permissive or whether an increase in NKB is required. In rats and mice, the intraventricular administration of NKB or its synthetic analogue, senktide, decreases LH secretion (Sandoval-Guzman and Rance, 2004; Navarro et al., 2009), whereas in humans and sheep, NKB has a stimulatory effect on GnRH/LH release (Amstalden et al., 2010a; Topaloglu et al., 2010). Interestingly, intraventricular co-administration of NKB and kisspeptin in rats caused a significant increase in LH concentration compared with kiss 1 alone (Corander et al., 2010). Recent studies have demonstrated increased NKB and kisspeptin along with LH response to gonadectomy in both sexes in postpubertal mice. Such changes occur in females but not in males prepubertally, suggesting that gonadal hormone-independent mechanisms restrain kisspeptin/ NKB activation of male reproduction before puberty (Kauffman et al., 2007b). Similarly, gonadectomized juvenile monkeys do not display elevated LH before normal puberty nor do human males who have gonadal dysgenesis (Topaloglu et al., 2010). 
Kisspeptin is also a major player in the control of puberty onset by metabolic cues. Studies in female rats subjected to chronic caloric restriction during puberty have demonstrated a detectable suppression of kiss 1 expression in the ARC (Castellano et al., 2009; Roa et al., 2010) and pharmacological treatment with kisspeptin at the expected time of puberty was sufficient to rescue vaginal opening and induce a potent gonadotropin response (Roa et al., 2010). Preliminary evidence from postnatal undernutrition of female rats indicates that leptin is an important regulator of kisspeptin expression at the time of puberty: there is a strict correlation between low circulating leptin levels and hypothalamic levels of kiss 1 mRNA and number of kisspeptin neurons (Roa et al., 2010).

Among other possible candidates, ghrelin, as a circulating orexigenic factor that signals energy insufficiency, has emerged as a putative modifier of the timing of puberty (Roa et al., 2010). Indeed, studies involving acute or repeated administration of ghrelin in pubertal rats support the function of ghrelin as a putative modulator of puberty having a predominantly inhibitory action (Forbes et al., 2009; Roa et al., 2010). Ghrelin may operate in the hypothalamus as a putative inhibitory regulator of kisspeptin expression and be able to suppress the kiss 1 gene in the preoptic area in rats (Forbes et al., 2009). A progressive decline in circulating ghrelin levels during puberty in humans suggests that ghrelin may play a permissive role in puberty onset, assuming a similar inhibitory action on gonadotropin secretion (Roa et al., 2010).

\section{EFFECTS OF PHOTOPERIOD AND NUTRITIONAL CUES ON KISSPEPTIN LEVELS IN THE HYPOTHALAMUS AND ON REPRODUCTIVE ACTIVITY IN SEASONALLY BREEDING SPECIES}

It is generally accepted that annual cycles of reproduction in sheep and other seasonal breeders are primarily induced by photic-mediated changes in the activity of several neuroendocrine systems and their functions in controlling GnRH secretion (Adams et al., 2006) and GnRH receptor (GnRHR) gene expression (Ciechanowska et al., 2010). The neural mechanisms responsible for transition of photic-signals into GnRH cells are not yet completely elucidated. Recent studies have indicated that seasonally breeding animals use a combination of photic and nonphotic (temperature, food availability) signals for regulation of reproduction (Paul et al., 2009a; Prendergast, 2010). To maximize reproductive success, animals restrict breeding to the optimal time of year, when internal physiology and external environmental conditions are suitable for the survival of both parent and offspring. It has been recognized that melatonin signals, which encode photoperiods, act within the mediobasal hypothalamus in sheep to control GnRH secretion (Malpaux et al., 1998) through neural pathways including dopaminergic (Goodman et al., 2010), noradrenergic (Goodman et al., 1995), serotoninergic 
(Le Corre and Chemineau, 1993), opioidergic (Skinner and Herbison, 1997), GABAergic (Scott and Clarke, 1993) and other pathways.

After the discovery of kisspeptins, it was shown that this peptide may also be involved in the seasonal messages of melatonin in generation of annual cycles in reproduction (Maywood et al., 1996).

In the ewe, a short-day breeding species, kiss 1 mRNA in the middle and caudal ARC, which displays a stimulatory effect on GnRH release, is lower during seasonal anoestrus than during the breeding season (Smith et al., 2007). Maximal expression of kiss 1 mRNA in the caudal ARC of sheep was observed during treatment with a photoperiod mimicking short days, and minimal expression, during long-day treatment (Wagner et al., 2008). An increase in kisspeptin neurons was detected in the POA and caudal ARC after transition to a short day (Chalivoix et al., 2010). It is suggested that these differences between kiss $1 \mathrm{mRNA}$ and number of kisspeptin neurons in the POA and ARC may result from an increase in kisspeptin synthesis under short-day conditions. It has also been reported that the photoperiod exerts a considerable influence on the number of kisspeptin opposition on GnRH cells in the sheep hypothalamus with a highest synaptic density during the breeding season (Smith et al., 2007). It is likely that the morphological rearrangements of kisspeptin neurons in the hypothalamus between the breeding and non-breeding period lead to differences in the gonadotropic response to kisspeptin in various functional states of the ewe reproductive axis. Similarly, morphological rearrangements in the organum vasculosum of the lamina terminalis (OVLT)/POA neurons and A15 dopaminergic neurons have been observed in adult ewes during different seasons of reproduction (Xiong et al., 1997; Adams et al., 2006).

In most photoperiodic rodents, the short photoperiod, which triggers gonadal regression, usually leads to decreases in kiss $1 \mathrm{mRNA}$ and its respective protein expression in the AVPV (Paul et al., 2009a). Indeed, levels of kiss 1 mRNA in the ARC in male Syrian hamsters are reduced after transfer from long- to short-day conditions, which leads to reproductive quiescence (Revel et al., 2006). These seasonal changes in kiss 1 mRNA appear to be melatonin-dependent, because pineal gland ablation blocks this short-day-induced down-regulation of kisspeptin expression, and melatonin-induced atrophy of the reproductive system (Revel et al., 2006). Chronic infusion of kiss 1 restores testicular activity in Syrian hamsters despite persisting photoinhibitory conditions (Revel et al., 2006).

Both male and female Siberian hamsters held under short-day conditions exhibit reduced responses to exogenous kisspeptin treatment and show negligible kiss 1 expression in the AVPV and its high expression in the ARC (Mason et al., 2007). Under long-day conditions, these expressions are reversed, with a marked level in the AVPV and only a minor one in the ARC (Greives et al., 2007; Mason et al., 2007). This indicates that responses in kisspeptin expression to photoperiod may be species-specific. 
A recently developed experimental method whereby nonphotic seasonal regulation of reproduction is investigated under a static photoperiod has provided novel insights into the environmental influence through the kisspeptin system on GnRH/LH secretion (Paul et al., 2009a). It has been shown that modest reduction of food availability decreases kiss 1 mRNA at the level of the ARC of male Siberian hamsters either by down-regulation of kiss 1 transcription or by increasing posttranscriptional processes. These data are consistent with reports in other nonphotoperiodic species (Levis et al., 2002; Smith et al., 2006c). At the level of the AVPV, neither photoperiod nor food restriction affected kiss 1 mRNA expression in this species. Recent studies have shown that another hypothalamic RF amide peptide, RFRP-3, may figure predominantly in transduction of inhibitory signals to the hypothalamic-pituitary-gonadal axis. At the level of $\mathrm{DMH}$, food restriction does not alter RFRP-3 gene expression; exposure of Siberian hamsters to intermediate photoperiod does, however, increase RFRP-3 mRNA expression in this structure. This indicates that nonphotic (reduced food availability) and photic (intermediate day lengths) stimuli are inadequate to impact reproductive physiology. In neither the ARC nor DMH were additive effects of food restriction on physiological events observed. Gonadal responses were only associated with changes in both ARC kiss $1 \mathrm{mRNA}$ and DMH RFRP-3; such a pattern of responses is consistent with a role of the RF amide system as an integrator of multimodal seasonal cues in reproduction. This regional and neuropeptide-specific activity of these systems may provide a mechanism for integration of photic and nonphotic action in the seasonal control of reproduction.

\section{CONCLUSIONS}

The accumulated evidence indicates that kisspeptin neurons, located in species-specific areas of the hypothalamus, are involved in the stimulation and/ or inhibition of $\mathrm{GnRH} / \mathrm{LH}$ secretion during different physiological states of animals. The action of kisspeptin neurons on GnRH activity in the hypothalamus is multifactorial and is dependent to a high degree upon steroid hormones, various peptides, and metabolic signals. The kisspeptin-GPR 54 system also participates in the mechanisms of puberty onset, the effect of gonadal steroids in the early postnatal period on the pulsatile pattern of LH secretion in adults, and the influence of photoperiod and metabolic factors on the activity of the hypothalamic-pituitarygonadal axis in seasonally breeding animals. 


\section{REFERENCES}

Adams V.L., Goodman R.L., Salm A.K., Coolen L.M., Karsch F.J., Lehman M.N., 2006. Morphological plasticity in the neural circuitry responsible for seasonal breeding in the ewe. Endocrinology 147, 4843-4851

Agata R., Matsuzaki T., Iwasa T., Kiyokawa M., Tanaka N., Kuwahara A., Yasui T., Irahara M., 2009. Hypothalamic ghrelin suppress pulsatile secretion of luteinizing hormone via $\beta$-endorphin in ovariectomized rats. Neuroendocrinology 90, 364-370

Ahima R.S., Hileman S.M., 2000. Postnatal regulation of hypothalamic neuropeptide Y expression by leptin: implications for energy balance and body weight regulation. Regul. Peptides 92, 1-7

Amstalden M., Coolen L.M., Hemmerle A.M., Billings H.J., Connors J.M., Goodman R.L., Lehman M.N., 2010a. Neurokinin 3 receptor immunoreactivity in the septal region, preoptic area and hypothalamus of the female sheep: colocalisation in neurokinin B cells of the arcuate nucleus but not in gonadotropin-releasing hormone neurons. J. Neuroendocrinol. 22, 1-12

Amstalden M., Redmond J.S., Baez-Sandoval G.M., Spell M., Spencer T.E., Lents C.A., Williams G.L., 2010b. Kiss-1 gene expression in the arcuate nucleus increases during activation of pulsatile release of LH in maturing ewe lambs. In: Proceedings of the $7^{\text {th }}$ International Congress of Neuroendocrinology. Rouen (France), Abstr., p.80

Backholer K., Bowden M., Gamber K., Bjorback C., Igbal J., Clarke I.J., 2010a. Melanocortins mimic the effects of leptin to restore reproductive function in lean hypogonadotropic ewes. Neuroendocrinology 91, 27-40

Backholer K., Smith J.T., Clarke I.J., 2009. Melanocortins may stimulate reproduction by activated orexin neurons in the dorsomedial hypothalamus and kisspeptin neurons in the preoptic area of the ewe. Endocrinology 150, 5488-5497

Backholer K., Smith J.T., Rao A., Pereira A., Igbal J., Ogawa S., Li C., Clarke I.J., 2010b. Kisspeptin cells in the ewe brain respond to leptin and communicate with neuropeptide $\mathrm{Y}$ and proopiomelanocortin cells. Endocrinology 151, 2233-2243

Bateman H.L., Palisaul H.B., 2008. Disrupted female reproductive physiology following neonatal exposure to phytooestrogens or oestrogen specific ligands is associated with decreased GnRH activation and kisspeptin fiber density in the hypothalamus. Neurotoxicology 29, 988-997

Bellefontain N., Hanchate N.K., Parkash J., Campagne C., deSeranno S., Clasadonte J., d'Anglemont de Tassigny X., Prevot V., 2011. Nitric oxide as key mediator of neuron-to-neuron and endothelia-to-glia communication involved in the neuroendocrine control of reproduction. Neuroendocrinology 93, 74-89

Billings H.J., Connors J.M., Altman S.N., Hileman S.M., Halaskova I., Lehman M.N., Mc Manus C.J., Nestor C.C., Jacobs R.H., Goodman R.L., 2010. Neurokinin B acts via neurokinin-3 receptor in the retrochiasmatic area to stimulate luteininzing hormone secretion in sheep. Endocrinology 151, 3836-3846

Briggs D.J., Andrews Z.B., 2011. Metabolic status regulates ghrelin function on energy homeostasis. Neuroendocrinology 93, 48-57

Brown R.E., Imran S.A., Ur E., Wilkinson M., 2008. Kiss-1 mRNA in adipose tissue is regulated by sex hormones and food intake. Mol. Cell. Endocrinol. 281, 64-72

Caraty A., Franceschini I., Hoffman G.E., 2010. Kisspeptin and the preovulatory gonadotropinreleasing hormone, luteinizing hormone surge in the ewe: basic aspects and potential applications in the control of ovulation. J. Neuroendocrinol. 22, 710-715

Caraty A., Smith J.T., Lanet D., Ben Said S., Morrisay A., Congée J., Doughton B., Baril G., Briant C., Clarke I.J., 2007. Kisspeptin synchronizes preovulatory surges in cyclical ewes and causes ovulation in seasonally acyclic ewes. Endocrinology 148, 5258-5267 
Castellano J.M., Navarro V.M., Fernandez-Fernandez R., Castano J.P., Malagon M.N., Aguilar E., Dieguez C., Magui P., Pinilla L., Tena-Sempere M., 2006. Ontogeny and mechanisms of action for the stimulatory effect of kisspeptin on gonadotropin-releasing hormone system of the rat. Mol. Cell. Endocrinol. 258, 75-83

Castellano J.M., Navarro V.M., Fernandez-Fernandez R., et al., 2005. Changes in hypothalamic kiss 1 system and restoration of pubertal activation of the reproductive axis by kisspeptin undernutrition. Endocrinology 146, 3917-3925

Castellano J.M., Roa J., Lugue R.M., Dieguez C., Aguilar E., Pinilla L., Tena-Sempere M., 2009. Kiss 1/kisspeptins and the metabolic control of reproduction: Physiologic roles and putative physiopathological implications. Peptides 30, 139-145

Chalivoix S., Bagnolini A., Caraty A., Cognie J., Malpaux B., Dufourny L., 2010. Effects of photoperiod on kisspeptin neural populations of the ewe diencephalon in connection with reproductive function. J. Neuroendocrinol. 22, 110-118

Chan Y.M., Broder-Fingert S., Seminara S.B., 2009a. Reproductive functions of kisspeptin and GPR54 across the life cycle of mice and men. Peptides 30, 42-48

Chan Y.M., Broder-Fingert S., Wong K.M., Seminara S.B., 2009b. Kisspeptin/Gpr 54 - independent gonadotropin-releasing hormone activity in kiss 1 and Gpr 54 mutant mice. J. Neuroendocrinol. $21,1015-1023$

Cheng G., Coolen L.M., Padmanabhan V., Goodman R.L., Lehman M.N., 2010. The kisspeptin/ neurokinin/dynorphin (KNDy) cell population of the arcuate nucleus: sex differences and effects of prenatal testosterone in sheep. Endocrinology 151, 301-311

Ciechanowska M., Łapot M., Mateusiak K., Przekop F., 2010. Neuroendocrine regulation of GnRH release, and expression of GnRH and GnRH receptor (GnRH-R) genes in the hypothalamicpituitary unit in different physiological states. Reprod. Biol. 10, 85-124

Ciofi P., Leray D., Tramu G., 2006. Sexual dimorphism in the organization of the rat hypothalamic infundibular area. Neuroscience 141, 1731-1745

Clarke I.J., Backholer K., Tilbrook A.J., 2005. Y 2 receptor-selective agonist delays the estrogeninduced luteinizing hormone surge in ovariectomized ewes, but $Y_{1}$ receptor selective agonist stimulates voluntary food intake. Endocrinology 146, 769-775

Clarke I.J., Scaramuzzi R.J., Short R.V., 1997. Ovulation in prenatally androgemized ewes. J. Endocrinol. 73, 385-389

Clarkson J., Boon W.C., Simpson E.R., Herbison A.E., 2009. Postnatal development of an estradiolkisspeptin feedback mechanism implicated in puberty onset. Endocrinology 150, 3214-3220

Clarkson J., D’Anglemont de Tassigny X., Moreno A.S., Colledge W.H., Herbison A.E., 2007. Kisspeptin GPR54 signaling is essential for preovulatory gonadotropin-releasing hormone neuron activation and the luteinizing hormone surge. J. Neurosci. 28, 8691-8697

Clarkson J., Han K., Lin X., Lee K., Herbison A.E., 2010. Neurobiological mechanisms underlying kisspeptin activation of gonadotropin-releasing hormone $(\mathrm{GnRH})$ neurons at puberty. Mol. Cell. Endocrinol. 324, 45-50

Corander M.P., Challis B.G., Thompson E.L. et al., 2010. The effect of neurokinin B upon gonadotrophin release in male rodents. J. Neuroendocrinol. 22, 181-187

Corbier P., 1985. Sexual differentiation of positive feedback: effect of hour of castration at birth on estradiol-induced luteinizing hormone secretion in immature male rat. Endocrinology $116,142-147$

D’Anglemont de Tassigny X., Ackroyd K.J., Chatzidaki E.E., Colledge W.H., 2010. Kisspeptin and NMDA signaling in the neuroendocrine mouse brain. In: Proceedings of the $7^{\text {th }}$ International Congress of Neuroendocrinology. Rouen (France), Abstr., p. 86

Donato J.R., Cravo R.M., Frazao R., Elias C.F., 2011. Hypothalamic sites of leptin action linking metabolism and reproduction. Neuroendocrinology 93, 9-18 
Dungan H.M., Gottsch M.L., Zeng H., Gragerov A., Bergmann J.E., Vassilatis D.K., Clifton D.K., Steiner R.A., 2007. The role of kisspeptin-GPR54 signaling in the tonic regulation and surge release of gonadotropin-releasing hormone/luteinizing hormone. J. Neurosci. 27, 1208812095

Felip A., Zanury S., Pineda R., Pinilla L., Carrillo M., Tena-Sempere M., Gomez A., 2009. Evidence for two distinct kiss genes in non-placental vertebrates that encode kisspeptin with different gonadotropin-releasing activities in fish and mammals. Mol. Cell. Endocrinol. 312, 61-71

Fernandez-Fernandez R., Martini A.C., Navarro V.M., Castellano J.M., Dieguez C., Aguilar E., Pinilla L., Tena-Sempere M., 2006. Novel signals for the intergration of energy balance and reproduction. Mol. Cell. Endocrinol. 254/255, 127-132

Foradori C.D., Amstalden M., Goodman R.L., Lehman M.N., 2006. Colocalization of dynorphin $\mathrm{A}$ and neurokinin B immunoreactivity in the arcuate nucleus and median eminence. J. Neuroendocrinol. 18, 534-544

Forbes S., Li X.F., Kinsey-Jones J., O'Byrne K., 2009. Effects of grelin on kisspeptin mRNA expression in the hypothalamic medial preoptic area and pulsatile luteinizing hormone secretion in the female rat. Neurosci. Lett. 460, 143-147

Foster D.L., Jackson L.M., Padmanabhan V., 2006. Programming of GnRH feedback controls timing puberty and adult reproductive activity. Mol. Cell. Endocrinol. 255, 109-119

George J.T., Millar R.P., Anderson R.A., 2011. Hypothesis: kisspeptin mediates male hypogonadism in obesity and type 2 diabetes. Neuroendocrinology 91, 302-307

Glidewell-Kenney C., Hurley L.A., Pfaff L., Weiss J., Levine J.E., Jameson J.L., 2007. Nonclassical estrogen receptor $\alpha$ signaling mediates negative feedback in the female mouse reproductive axis. Proc. Nat. Acad. Sci. USA 104, 8173-8177

Goodman R.L., Jansen H.T., Billings H.J., Coolen L.M., Lehman M.N., 2010. Neural systems mediating seasonal breeding in the ewe. J. Neuroendocrinol. 22, 674-681

Goodman R.L., Lehman M.N., Smith J.T. et al., 2007. Kisspeptin neurons in the arcuate nucleus of the ewe express both dynorphin A and neurokinin B. Endocrinology 148, 5752-5760

Goodman R.L., Robinson J.E., Kendrick K.M., Dyer R.G., 1995. Is the inhibitory action of estradiol on luteinizing hormone pulse frequency in anestrous ewes mediated by noradrenergic neurons in the preoptic area? Neuroendocrinology 61, 284-292

Gottsch M.N., Navarro V.M., Zhao Z., Glidewell-Kenney C., Weiss J., Jameson J.C., Clifton D.K., Levine J.E., Steiner R.A., 2009. Regulation of kiss 1 and dynorphin gene expression in the murine brain by classical and nonclassical estrogen receptor pathways. J. Neurosci. 29, 93909395

Greives T.J., Mason A.O., Levine J., Ketterson E.D., Kriegsfeld L.I., Demas G.E., 2007. Environmental control of kisspeptin: implications for seasonal reproduction. Endocrinology $148,1158-1166$

Han S.K., Gottsch M.L., Lee K.J., Popa S.M., Smith J.T., Jakawich S.K., Clifton D.K., Steiner R.A., Herbison A.E., 2005. Activation of gonadotropin-releasing hormone neurons by kisspeptin as a neuroendocrine switch for the onset of puberty. J. Neurosci. 25, 11349-11356

Handa R.J., Gorski R.A., 1985. Alternations in the onset of ovulatory failure and gonadotropin secretion following steroid administration to lightly androgenized female rats. Biol. Reprod. 32, 248-256

Herbison A.E., D’Anglemont de Tassigny X., Doran J., Colledge W.H., 2010. Distribution and postnatal development of GPR 54 gene expression in the mouse brain and gonadotropinreleasing hormone neurons. Endocrinology 151, 312-321

Homma T., Sakakibara M., Yamada S. et al., 2009. Significance of neonatal testicular sex steroids to determinizm anteroventral periventricular kisspeptin neurons and the GnRH/LH surge system in male rats. Biol. Reprod. 81, 1216-1225 
Irwing M.S., Fraley G.S., Smith J.T., Acohido B.V., Popa S.M., Cunningham M.J., Gottsch M.L., Clifton D.K., Steiner R.A., 2004. Kisspeptin activation of gonadotropin releasing hormone neurons and regulation of kiss-1 mRNA in the male rat. Neuroendocrinology 80, 264-272

Kauffman A.S., Clifton D.K., Steiner R.A., 2007a. Emerging ideas about kisspeptin: GPR 54 signaling in the neuroendocrine regulation of reproduction. Trends Neurosci. 30, 504-511

Kauffman A.S., Gottsch M.L., Roa J., Byquist A.C., Crown A., Clifton D.K., Hoffman G.E., Steiner R.A., Tena-Sempere M., 2007b. Sexual differentiation of kiss 1 gene expression in the brain of the rat. Endocrinology 148, 1774-1783

Kauffman A.S., Navarro V.M., Clifton D.K., Steiner R.A., 2009. Sex differences in the regulation of kiss $1 / \mathrm{NKB}$ neurons in juvenile mice: implications for the timing of puberty. Amer. J. Physiol.Endocrinol. Met. 297, 1212-1221

Keen K.L., Wagner F.H., Bloom S.R., Ghatei M.A., Terasawa E., 2008. An increase in kisspeptin-54 release occurs with the pubertal increase in luteinizing hormone-releasing hormone-1 release in the stalk-median eminence female rhesus monkeys in vivo. Endocrinology 149, 4151-4157

Kim G.L., Dhillon S.S., Belsham D.D., 2010. Kisspeptin directly regulates NPY synthesis and secretion via ERK $1 / 2$ and $\mathrm{p} 38 \mathrm{MAPK}$ signaling pathways in an NPY-secreting hypothalamic cell line. In: Proceedings of the $7^{\text {th }}$ International Congress of Neuroendocrinology. Rouen (France), Abstr. p. 104

Kim W., Jessen H.M., Auger A.P., Terasawa E., 2009. Postmenopausal increase in kiss-1, GPR 54 , and luteinizing hormone-releasing hormone (LHRH) mRNA in the basal hypothalamus of female rhesus monkeys. Peptides 30, 103-110

Kinoshita M., Tsukamura H., Adachi S. et al., 2005. Involvement of central metastin in the regulation of preovulatory luteinizing hormone surge and estrous cyclicity in female rats. Endocrinology $146,4431-4436$

Kotani M., Detheus M., Vandenbogaerde A., Communi D., Vanderwinden F., Blanpain C., Schiffman S.N., Vassart G., Parmentier M., 2001. The metastasis suppressor gene kiss-1 encodes kisspeptins, the natural ligands of the orphan G protein-coupled receptor GPR-54. J. Biol. Chem. 276, 34631-34636

Kurose Y., Igbal J., Rao A., Murata Y., Hasegawa Y., Terashima Y., Kojina M., Kangawa K., Clarke I.J., 2005. Changes in the expression of the genes for the leptin receptor and growth hormone-releasing peptide/ghrelin receptor in the hypothalamic arcuate nucleus with long term manipulation of adiposity by dietary means. J. Neuroendocrinol. 17, 331-340

Le Corre S., Chemineau P., 1993. Control of photoperiodic inhibition of luteinizing hormone secretion by dopaminergic and serotoninergic systems in ovariectomized Ile-de-France ewes supplemented with estradiol. J. Reprod. Fertil. 97, 367-373

Lee Y.R., Tsunekawa K., Moon M.J., Um H.N. et al., 2009. Molecular evolution of multiple forms of kisspeptins and GPR 54 receptors in vertebrates. Endocrinology 150, 2837-2846

Lehman M.N., Coolen L.M., Goodman R.L., 2010. Minireviews: kisspeptin/neurokinin B/dynorphin (KNDy) cells of the arcuate nucleus; a central notre in the control of gonadotropin-releasing hormone secretion. Endocrinology 151, 3479-3489

Levis D., Freemom D.A., Dark J., Wynne-Edwards K.E., Zucker I., 2002. Photoperiodic control of oestrous cycles in Syrian hamsters: mediation by the mediobasal hypothalamus. J. Neuroendocrinol. 14, 294-299

Malpaux B., Daveau A., Maurice-Mandon F., Duarte G., Chemineau P., 1998. Evidence that melatonin acts in the premammillary hypothalamic area to control reproduction in the ewes presence of binding sites and stimulation of luteinizing hormone secretion by in situ microimplant delivery. Endocrinology 139, 1508-1516 
Mason A.O., Greives T.J., Scotti M.A., Levine J., Frommeyer S., Ketterson E.D., Demas G.E., Kriegsfeld L.I., 2007. Suppression of kisspeptin expression and gonadal axis sensitivity following exposure to inhibitory day lengths in female Siberian hamsters. Hormone Behav. 52, 492-498

Maywood E.S., Bittman E.L., Hastings M.H., 1996. Lesions of the melatonin-and androgenresponsive tissue of the dorsomedial nucleus of the hypothalamus block the gonadal response of male Syrian hamsters to programmed infusion of melatonin. Biol. Reprod. 54, 470-477

Messager S., Chatzidaki E.E., Ma D. et al., 2005. Kisspeptin directly stimulates gonadotropinreleasing hormone release via G protein-coupled receptor 54. Proc. Nat. Acad. Sci. USA 102, 1761-1766

Muir A.I., Chamberlain L., Elshourbagy N.A. et al., 2001. AXOR 12, a novel human G proteincoupled receptors activated by the peptide kiss-1. J. Biol. Chem. 276, 28969-28975

Navarro V.M., Castellano J.M., Fernandez-Fernandez R., Barreiro M.L., Roa J., Sanchez-Criado J.E., Aouilar E., Dieguez C., Pinilla L., Tena-Sempere M., 2004. Developmental and hormonally regulated messenger ribonucleic acid expression of kiss-1 and its putative receptor, GPR54, in rat hypothalamus and potent luteinizing hormone-releasing hormone activity of kiss-1 peptide. Endocrinology 145, 4565-4572

Navarro V.M., Castellano J.M., Fernandez-Fernandez R., Tovar S., Mayen A., Nogueiras R., Vazquez C., Pinilla L., Tena-Sempere M., 2005a. Characterization of the potent luteinizing hormonereleasing hormone activity of kiss-1 peptide, the natural ligand of GPR54. Endocrinology $146,156-163$

Navarro V.M., Castellano J.M., Fernandez-Fernandez R. et al., 2005b. Effect of kiss-1 peptide, the natural ligand of GPR-54 on follicle stimulating hormone secretion in the rat. Endocrinology $146,1689-1697$

Navarro V.M., Gottsch M.L., Chavkin C., Okamura H., Clifton D.K., Steiner R.A., 2009. Regulation of gonadotropin-releasing hormone secretion by kisspeptin/neurokinin B neurons in the arcuate nucleus of the mouse. J. Neurosci. 29, 11859-11866

Oakley A.E., Clifton D.K., Steiner R.A., 2009. Kisspeptin signaling in the brain. Endocr. Rev. 30, 731-743

Ohtaki T., Shintani Y., Honda S. et al., 2001. Metastasis suppressor gene kiss-1 encodes peptide ligand of a G-protein-coupled receptor. Nature 411, 613-617

Ojeda S.R., Skinner M.N., 2006. Puberty in the rat. In: J.D. Neill (Editor). The Physiology of Reproduction. Academic Press/Elsevier. San Diego, CA, pp. 2061-2126

Paul M.J., Pytel L.M., Freeman D.A., Galang J., Prendergast B.J., 2009a. Photic and nonphotic seasonal cues differentially engage hypothalamic kisspeptin and RF-amide-related peptide mRNA expression in Siberian hamsters. J. Neuroendocrinol. 21, 1007-1014

Paul M.J., Schwartz W.J., Prendergast B.J., 2009b. Intermediate-duration day lengths unmask reproductive responses to nonphotic environmental cues. Amer. J. Physiol. 296, R1613R1619

Pielecka-Fortuna J., Moenter S.M., 2010. Kisspeptin increases $\gamma$-aminobutyric acidergic and glutamatergic transmission directly to gonadotropin-releasing hormone neurons in an estradioldependent manner. Endocrinology 151, 291-300

Pineda R., Garcia-Galiano D., Rosewei A., Romero M., Sanchez-Garrido M.A., Ruiz-Pino F., Morgan K., Pinilla L., Millar R.P., Tena-Sempere M., 2010. Critical role of kisspeptin in female puberty and preovulatory gonadotropin surges as revealed by novel antagonist. Endocrinology $151,722-730$

Plant T.M., 2006. The male monkey as a model for the study of the neuroendocrinology of puberty onset in man. Mol. Cell. Endocrinol. 255, 97-102 
Plant T.M., Ramaswamy S., Dipietro M.J., 2006. Repetive activation of hypothalamic G-protein coupled receptor 54 with intravenous pulses of kisspeptin in juvenile monkey (Macaza mulata) elicits a sustained train of gonadotropin-releasing hormone discharges. Endocrinology 147, 1007-1013

Plant T.M., Witchel S.M., 2006. Puberty in non-human primates and humans. In: J.D. Neill (Editor). Physiology of Reproduction. $3^{\text {rd }}$ Edition. Knobil and Neill's. Amsterdam, Elsevier, pp. 2177-2230

Pompolo S., Pereira A., Estrada K.M., Clarke I.J., 2006. Colocalization of kisspeptin and gonadotropin-releasing hormone in the ovine brain. Endocrinology 147, 804-810

Prendergast B.J., 2010. MT 1 melatonin receptors mediate somatic, behavioral and reproductive neuroendocrine responses to photoperiod and melatonin in Siberian hamsters (Phodopus sungorus). Endocrinology 151, 714-721

Quennel J.H., Mulligan A.C., Tups A., Liu X., Phipps S.J., Kemp C.J., Herbison A.E., Grattan D.R., Anderson G.M., 2009. Leptin indirectly regulates gonadotropin releasing hormone neuronal function. Endocrinology 150, 2805-2812

Ramaswamy S., Guerriero K.A., Gibbs R.B., Plant T.M., 2008. Structural interactions between kisspeptin and GnRH neurons in the medial basal hypothalamus of the male rhesus monkey (Macaca mulata) as revealed by double immunofluoroscence and confocal microscopy. Endocrinology 149, 4387-4395

Revel F.G., Ansel L., Klosen P., Saboureasu M., Pevet P., Mikkelsen J.D., Simonneaux V., 2007. Kisspeptin: a key link to seasonal breeding. Rev. Endocr. Metab. Disord. 8, 57-65

Revel F.G., Saboureau M., Masson-Pevet M., Pevet P., Mikkelsen J.D., Simonneaux X.V., 2006. Kisspeptin mediates photoperiodic control of reproduction hamsters. Curr. Biol. 16, 17301735

Richard N., Galmiche G., Corvaisier S., Caraty A., Kottler M.L., 2008. Kiss-1 and GPR 54 gene are co-expressed in rat gonadotrophs and differentially regulated in vivo by oestradiol and gonadotrophin-releasing hormone. J. Neuroendocrinol. 20, 381-393

Roa J., Garcia-Galiano D., Castellano J.M., Gaytan F., Pinilla L., Tena-Sempere M., 2010. Metabolic control of puberty onset: new players, new mechanisms. Mol. Cell. Endocrinol. 324, 87-94

Roa J., Wigo E., Garcia-Galiano D., Castelonzo J.M., Navarro V.M., Pineda R., Dieguez C., Aguilar E., Pinilla L., Tena-Sempere M., 2008. Desensitization of gonadotropin responses to kisspeptin in the female rat: analysis of LH and FSH secretion at different developmental and metabolic states. Amer. J. Physiol. 294, E1088-E1096

Robinson J.E., Forsdike R.A., Taylor J.A., 1999. In utero exposure of female lambs to testosterone reduces the sensitivity of the gonadotropin-releasing hormone neuronal network to inhibition by progesterone. Endocrinology 140, 5797-5805

Roseweir A.K., Kauffman A.S., Smith J.T. et al., 2009. Discovery of potent kisspeptin antagonists delineate physiological mechanisms of gonadotropin regulation. J. Neurosci. 29, 3920-3929

Roseweir A., Kauffman A., Smith J.T. et al., 2010. Kisspeptin antagonists reveal kisspeptin's neuroendocrine role in reproduction. In: Proceedings of the $7^{\text {th }}$ International Congress of Neuroendocrinology. Rouen (France), Abstr. p.60

Roseweir A., Millar R.P., 2009. The role of kisspeptin in the control of gonadotropin secretion. Hum. Reprod. Update 15, 203-212

Sandoval-Guzman T., Rance N.E., 2004. Central injection of senktil, an NK3 receptor agonist, or neuropeptide $\mathrm{Y}$ inhibits $\mathrm{LH}$ secretion and induces different patterns of for expression in the rat hypothalamus. Brain Res. 1026, 307-312.

Scott C.J., Clarke I.J., 1993. Inhibition of luteinizing hormone secretion in ovariectomized ewes during the breeding season by $\gamma$-aminobutyric acid (GABA) is mediated by GABA-A receptors, but not GABA-B receptors. Endocrinology 132, 1789-1796 
Seminara S.B., Dipietro M.J., Ramaswamy S., Crowley Jr. W.F., Plant T.M., 2006. Continuous human metastin 45-54 infusion desensitizes G-protein-coupled receptor 54-induced gonadotropinreleaseing hormone release monitored indirectly in the juvenile male rhesus monkey (Macaca mulata): finding with therapeutic implications. Endocrinology 147, 2122-2126

Seminara S.B., Messager S., Chatzidaki E.E. et al., 2003. The GPR54 gene as a regulator of puberty. N. Engl. J. Med. 349, 1614-1627

Shahab M., Mastronardi C., Seminara S.B., Crowley W.F., Ojeda S.R., Plant T.M., 2005. Increased hypothalamic GPR 54 signaling: a potential mechanism for initiation of puberty in primates. Proc. Nat. Acad. Sci. USA 102, 2129-2134

Skinner D.C., Herbison A.E., 1997. Effects of photoperiod on estrogen receptor, tyrosine hydroxylase, neuropeptide $\mathrm{Y}$, and $\beta$-endorphin immunoreactivity in the ewe hypothalamus. Endocrinology $138,2585-2595$

Smith J.T., Acohido B.V., Clitton D.K., Steiner R.A., 2006a. Kiss-1 neurons are direct targets for leptin in the $\mathrm{db} / \mathrm{db}$ mouse. J. Neuroendocrinol. 18, 298-303

Smith J.T., Clay C.M., Caraty A., Clarke I.J., 2007. Kiss 1 messenger ribonucleic acid expression in the hypothalamus of the ewe is regulated by sex steroids and season. Endocrinology 148, $1150-1157$

Smith J.T., Clifton D.K., Steiner R.A., 2006b. Regulation of neuroendocrine reproductive axis by kisspeptin-GPR 54 signaling. Reproduction 131, 623-630

Smith J.T., Coolen L.M., Kriegsfeld L.J. et al., 2008a. Variation in kisspeptin and RF amide-related peptide (RFRP-3) expression and terminal connections to gonadotropin-releasing hormone neurons in the brain: a novel medium for seasonal breeding in the sheep. Endocrinology 149, 5770-5782

Smith J.T., Li Q., Pereira A., Clarke I.J., 2009a. Kisspeptin neurons in the ovine arcuate nucleus and preoptic area involved in the preovulatory luteinizing hormone surge. Endocrinology 150, 5530-5538

Smith J.T., Popa S.M., Clifton D.K., Hoffman G.E., Steiner R.A., 2006c. Kiss 1 neurons in the forebrain as central processors for generating the preovulatory luteinizing hormone surge. J. Neurosci. 26, 6687-6694

Smith J.T., Rao A., Pereira A., Caraty A., Millar R.P., Clarke I.J., 2008b. Kisspeptin is present in ovine hypophysial blood but does not increase during the preovulatory luteinizing hormone surge evidence that gonadotropes are not direct targets of kisspeptin in vivo. Endocrinology 149, 1951-1959

Smith J.T., Salch S.N.H., Clarke I.J., 2009b. Seasonal and cyclical change in the luteinizing hormone response to kisspeptin in the ewe. Neuroendocrinology 90, 283-291

Smith J.T., Shahab M., Millar R., Clarke I.J., 2010. Kisspeptin antagonist reveals an important role for kisspeptin in the generation of the estrogen induced GnRH/LH surge in the ewe. In: Proceedings of the $7^{\text {th }}$ International Congress of Neuroendocrinology. Rouen (France), Abstr. p. 212

Terasawa E., Kurian J.R., Guerriero K.A., Kenealy B.P., Hutz E.D., Keen K.L., 2010. Recent discovery on the control of gonadotropin-releasing hormone neurons in nonhuman primates. J. Neuroendocrinol. 22, 630-638

Thompson E.I., Petterson M., Murphy K.G., Smith K.I., Dhillo W.S., Todd J.F., Ghatei M.A., Bloom J.F., 2004. Central and peripheral administration of kisspeptin-10 stimulates the hypothalamicpituitary-gonadal axis. J. Neuroendocrinol. 16, 850-858

Thornton J.E., Cheung C.C., Clifton D.K., Steiner R.A., 1997. Regulation of hypothalamic proopiomelanocortin mRNA by leptin in ob/ob mice. Endocrinology 138, 5063-5066

Topaloglu A.K., Kotan D.D., Yuksel B., 2010. Neurokinin B signaling in human puberty. J. Neuroendocrinol. 22, 765-770 
Tovar S., Vazquez M.J., Navarro V.M. et al., 2006. Effects of single or repeated intravenous administration of kisspeptin upon dynamic LH secretion in conscious male rat. Endocrinology $147,2696-2704$

Wagner G.C., Johnstone J.D., Clarke I.J., Lincoln G.A., Hazlerigg D.G., 2008. Redefining the limits of day length responsiveness in a seasonal mammal. Endocrinology 149, 32-39

Watanabe H., Schioth H.B., Wikberg J.E., Suda T., 1999. The melanocortin 4 receptor mediates leptin stimulation of luteinizing hormone and prolactin surges in steroid-primed ovariectomized rats. Biochem. Biophys. Res. Commun. 257, 860-864

West A., Vojta P.J., Welch D.R., Weisman B.E., 1998. Chromosome localization and genomic structure of the kiss-1 metastasis suppressor gene (Kiss1). Genomics 54, 145-148

Wu M., Dumalska I., Morozova E., Van Den Pol A.N., 2009. Gonadotropin inhibitory basal forebrain V Glut 2 - gonadotropin-releasing hormone neurons via direct postsynaptic mechanism. J. Physiol. 587, 1401-1411

Xiong J.J., Karsch F.J., Lehman M.N., 1997. Evidence for seasonal plasticity in the gonadotropinreleasing hormone $(\mathrm{GnRH})$ system in the ewe: changes in synaptic inputs onto GnRH neurons. Endocrinology 138, 1240-1250

Zhang C., Bosch M.A., Rennekleiv O.K., Kelly M.J., 2009. $\gamma$-aminobutyric acid B receptor mediated inhibition of gonadotropin-releasing hormone neurons is suppressed by kisspeptin-G proteincoupled receptor 54 signaling. Endocrinology 150, 2388-2394

Zhang C., Roepke T.A., Kelly M.J., Ronnekleiv O.K., 2008. Kisspeptin depolarizes gonadotropinreleasing hormone neurons through activation of TRPC-like cationic channels. J. Neurosci. 28, 4423-4434 